\title{
Aroma Volatile Profiles from Ripe Tomatoes are Influenced by Physiological Maturity at Harvest: An Application for Electronic Nose Technology
}

\author{
Fernando Maul, ${ }^{1}$ Steven A. Sargent, ${ }^{1}$ and Murat O. Balaban ${ }^{2}$ \\ University of Florida, Institute of Food and Agricultural Sciences, Gainesville, FL 32611 \\ Elizabeth A. Baldwin \\ Citrus and Subtropical Products Laboratory, U.S. Department of Agriculture-Agricultural Research \\ Service, P.O. Box 1909, Winter Haven, FL 33883 \\ Donald J. Huber ${ }^{1}$ and Charles A. Sims ${ }^{2}$ \\ University of Florida, Institute of Food and Agricultural Sciences, Gainesville, FL 32611
}

\begin{abstract}
ADDITIONAL INDEX WORDS. tomato aroma, electronic aroma sensing, multivariate discriminant analysis, Lycopersicon esculentum
ABSTRACT. The effect of physiological maturity at harvest on ripe tomato (Lycopersicon esculentum Mill.) volatile profiles was studied using ripening response time (in days) to $100 \mu \mathrm{L} \cdot \mathrm{L}^{-1}$ exogenous ethylene treatment as a tool to separate immature-green from mature-green fruit. Electronic nose (EN) sensor array and gas chromatography (GC) analyses were used to document volatile profile changes in tomatoes that required a 1-, 3-, or 5-day ethylene treatment to reach the breaker stage. EN output analysis using multivariate discriminant and canonical analyses classified intact tomato and whole tomato homogenate samples that required 3 or 5 days of ethylene treatment as significantly different $(P<0.01)$ from those that required only 1 day. The GC aroma profiles from whole tomato homogenate showed that 1-day fruit had significantly higher levels $(P<0.05)$ of 1-penten-3-one, cis-3-hexenal, 6-methyl-5-hepten-2-one, 2-isobutylthiazole, and geranylacetone when compared to 5-day fruit. Analysis of excised tomato tissues showed that pericarp (including columnella) produced an average $219 \%$ greater concentration of the 16 aroma volatiles quantified by $G C$ when compared to locular gel ( 442 and $203 \mu \mathrm{L} \cdot \mathrm{L}^{-1}$, respectively). EN analysis concurred with GC by showing greater average Mahalanobis distance between pericarp tissue groupings when compared to locular gel groupings (78.25 and 12.33 units, respectively). Pericarp tissue from the 5-day ethylene treatment showed significantly lower levels of 1-penten-3-one, trans-2-heptenal, 6-methyl-5-hepten-2-one, 2-isobutylthiazole, geranylacetone, and $\beta$-ionone compared to the 1- and 3-day treatments. Similarly, locular gel from the 3-and 5-day ethylene treatments had significantly lower levels of 1-penten-3-one, 2-isobutylthiazole, and 1-nitro-2-phenylethane compared to 1-day samples. cis-3-Hexenol in locular gel was the only volatile compound that showed significantly higher levels with increasing ethylene treatment. EN analysis showed greater Mahalanobis distances between 1- and 3-day ethylene samples than between 3- and 5-day ethylene samples (32.09 and 12.90, 24.14 and 6.52,116.31 and 65.04, and 15.74 and 13.28 units, for intact tomato, whole tomato, pericarp, and locular gel homogenate, respectively).
\end{abstract}

The flavor of fresh tomatoes results from the complex interaction between sugars, organic acids, minerals and aroma volatile compounds. Even though over 400 aroma compounds have been identified in fresh tomato samples, less than thirty compounds are considered of importance based on their odor thresholds (Buttery et al., 1988). Several publications have indicated that the following compounds play a key role in tomato flavor: hexanal, cis-3hexenal, trans-2-hexenal, 1-penten-3-one, 6-methyl-5-hepten-2one, $\beta$-ionone, ethanol, methanol, cis-3-hexenol, $2+3$ methylbutanol, 2-isobutylthiazole, and 1-nitro-2-phenylethane (Baldwin et al., 1991a; Buttery et al., 1990).

The consumer dissatisfaction with fresh tomato flavor promoted extensive research during the late 1970s and early 1980s. Tomatoes harvested at early stages of maturity were perceived as less sweet, more sour, and as having less tomato-like flavor

Received for publication 15 Jan. 1998. Accepted for publication 12 June 1998. Florida Agricultural Experiment Station journal series R-06109. We gratefully acknowledge the technical assistance of Holly Sisson, research biologist, USDAARS Winter Haven, Fla.; Diego Luzuriaga, research assistant, Food Science and Human Nutrition Dept., Univ. of Florida, for the electronic nose operation guidance, statistical analysis, and manuscript review; and Kenneth Shuler, Palm Beach County Agricultural Extension Service, for providing the tomatoes used for these experiments. The cost of publishing this paper was defrayed in part by the payment of page charges. Under postal regulations, this paper therefore must be hereby marked advertisement solely to indicate this fact.

Horticultural Science Department. Reprint requests should be sent to S.A. Sargent. ${ }^{2}$ Food Science and Human Nutrition Department. compared to those harvested more mature (Kader et al., 1977). Furthermore, vine-ripe fruit were considered sweeter by sensory panels without significant differences in soluble solids content or dry matter (Watada and Aulenbach, 1979). This observation highlighted the possible relevance of aroma compounds on tomato flavor perception. In contrast, tomatoes harvested at breaker stage $(<10 \%$ red coloration) were superior in flavor to either vine-ripe or green-harvested fruit (Kavanagh et al., 1986).

An electronic nose (EN) is a sensor-based instrument capable of detecting volatile compounds present in the headspace over a sample of interest. It is comprised of a series of nonspecific gas sensors that are useful for aroma discrimination since their electrical resistance properties are altered by the adsorption of volatile compounds produced by the sample. Volatile compounds responsible for fruit and vegetable aroma and those odorless to humans could elicit a response from the sensors (Anon, 1996). An EN combined with an appropriate pattern recognition procedure could offer the possibility of objective analysis of the volatile chemicals produced by vegetables and fruit.

Physiological maturity of green-harvested tomatoes has been circumstantially related to ripe, fresh tomato flavor and quality by numerous researchers (Al-Shaibani and Greig, 1979; Kader et al., 1977; Watada and Aulenbach, 1979). Nonetheless, chemical composition data collected by these authors did not always concur with their sensory panel results.

More than $85 \%$ of Florida's fresh market tomatoes are har- 
vested at a green stage and require exposure to exogenous ethylene treatment to accelerate onset of ripening processes. With a $49 \%$ average of immature-green harvested tomatoes (Chomchalow, 1991) in commercial green-harvest operations, consistent final eating quality of tomatoes may be compromised. Without an accurate and dependable nondestructive method of screening inferior quality immature fruit in green-harvest tomato operations, growers cannot provide the consistent quality that the markets demand. The development of locular gel has been proposed as an accurate way to separate immature-green (M1+M2) from maturegreen tomatoes (M3+M4) (Kader and Morris, 1976). Data collected in our laboratory over the past two years showed that there is a strong direct relationship between immature-green fruit (M1M2) and extended exposure to ethylene gas required to initiate external ripening symptoms.

The objectives of the present study were 1) to document changes in ripe tomato concentrations of important volatile compounds from different fruit tissues as affected by physiological maturity at harvest and 2) to explore the potential use of EN volatile sensing technology as a nondestructive tool to screen ripe tomatoes harvested at immature-green and mature-green stages.

\section{Materials and Methods}

Plant materials. Green-stage 'Solimar' tomatoes (Asgrow Seed Co., Kalamazoo, Mich.) were harvested at a commercial tomato field in Del Ray Beach, Fla., and were transported to Gainesville the same day. Before ethylene treatment, a random sample of fruit $(n=50)$ were sliced equatorially to assess the physiological maturity distribution of the fruit population. The physiological maturity stages were rated based on locular gel development (M1-M4) following the internal maturity standards for tomatoes proposed by Kader and Morris (1976). Tomatoes were gassed in bulk at $20^{\circ} \mathrm{C}$ with a humidified, $100 \mu \mathrm{L} \cdot \mathrm{L}^{-1}$ ethylene/air mixture inside sealed chambers connected to a flowthrough system. The flow rate calculation was based on maturegreen tomato $\mathrm{CO}_{2}$ respiratory rates for $20{ }^{\circ} \mathrm{C}\left(\mathrm{mg} \cdot \mathrm{kg}^{-1} \cdot \mathrm{h}^{-1}\right.$ fresh mass basis) (Hardenburg et al., 1986) and total fruit mass (kg) inside each chamber.

After 1,3, and $5 \mathrm{~d}$ of ethylene treatment, fruit at breaker stage were transferred to air at $20^{\circ} \mathrm{C}$ for ripening. Tomatoes were considered table-ripe upon attaining red stage ( $100 \%$ red coloration) and noticeable firmness loss ( $4 \mathrm{~mm}$ deformation threshold) measured by applying $9.8 \mathrm{~N}$ for $5 \mathrm{~s}$ on the fruit equator (Gull et al., 1980).

EN ANALYSIS. The EN consisted of a sampling head equipped with 12 polymer sensors, glass sampling vessel and purging valves (e-NOSE-4000, Neotronics Scientific Inc., Flowery Branch, Ga.). Each individual polymer sensor changed its electrical conductivity upon exposure to volatile compounds present inside the headspace of the sampling vessel. A computer recorded the sensor outputs over time.

$\mathrm{EN}$ analysis consisted of placing an individual intact fruit or a 20 - $\mathrm{mL}$ sample of fruit homogenate inside the sampling vessel $(\mathrm{n}=$ 6 fruit or homogenate samples per treatment) and sealing it against the sensor head. To eliminate any contaminating odors, the vessel was purged with compressed air for $2 \mathrm{~min}$. The sensor head was then purged for an additional $4 \mathrm{~min}$ to clean the sensors of any lingering volatiles. Meanwhile, volatile compounds from the tomato sample equilibrated inside the sealed sampling vessel. Both sampling vessel and sensor head were purged using compressed air at a $400-\mathrm{mL} \cdot \mathrm{min}^{-1}$ flow rate. Finally, the sensor head was lowered automatically into the sampling vessel to expose the polymer sensors to the volatile compounds produced by the sample in the headspace for an additional $4 \mathrm{~min}$. EN analysis was carried out at room temperature $\left(\approx 25^{\circ} \mathrm{C}\right)$ and relative humidity $(\mathrm{RH})$ inside the sampling vessel was also recorded. The EN analysis lasted a total of $10 \mathrm{~min}$ per sample.

Immediately after sampling, each fruit was sliced equatorially and the locular gel was separated from pericarp and columnella tissues on one half. The remaining half was analyzed intact (whole fruit sample). Each one of the fruit tissues (locular gel, pericarp, and combined) was homogenized for $30 \mathrm{~s}$ using a blender for comparison to gas chromatography (GC) quantification of volatiles in blended tissue. Six 20 -mL homogenate samples from each tomato tissue were placed inside the EN's sampling vessel for headspace analysis after tissue maceration.

Gas Chromatography. Tomato volatile compounds were identified and quantified using a headspace analysis technique (Baldwin et al., 1991b). Forty milliliters of homogenate from each tomato tissue sample was combined with $10-\mathrm{mL}$ of saturated $\mathrm{CaCl}_{2}$ solution, blended for $10 \mathrm{~s}$, immediately frozen using liquid nitrogen and stored at $-80^{\circ} \mathrm{C}$. The saturated $\mathrm{CaCl}_{2}$ solution was added to the tomato samples to help reduce enzymatic changes that might induce quantitative and qualitative changes in the tomato sample's volatile profile following tissue maceration (Buttery and Ling, 1993). For GC analysis, each tomato sample was thawed under running tap water and a $2-\mathrm{mL}$ sample placed inside a $6-\mathrm{mL}$ vial sealed with a crimp-top and Teflon-silicone septum. Vials were heated rapidly to $80^{\circ} \mathrm{C}$ and incubated for $15 \mathrm{~min}$ before injection to a Perkin Elmer HS-6 headspace sampler heating block. The analysis was carried out using a Perkin Elmer Model 8500 gas chromatograph equipped with a 0.53 $\mathrm{mm} \times 30 \mathrm{~m}$ polar stabilwax capillary column $(1.0-\mu \mathrm{m}$ film thickness, Restek Corp., Bellefonte, Pa.) and a flame ionization detector. Column oven temperature was held at $40^{\circ} \mathrm{C}$ for $6 \mathrm{~min}$, then raised to $180^{\circ} \mathrm{C}$ at a rate of $6^{\circ} \mathrm{C} / \mathrm{min}$. The resulting $\mathrm{GC}$ peak heights for the aroma volatile compounds of interest as reported in previous research (Baldwin et al., 1991a, 1991b, Buttery et al., 1988; McDonald et al., 1996; Petro-Turza, 1987) were quantified in $\mu \mathrm{L} \cdot \mathrm{L}^{-1}$ using standard curves for 16 important aroma volatile compounds (acetaldehyde, acetone, methanol, ethanol, 1-penten-3-one, hexanal, cis-3-hexenal, 2+3-methylbutanol, trans-2-hexenal, trans-2-heptenal, 6-methyl-5hepten-2-one, cis-3-hexenol, 1-nitro-2-phenylethane, geranylacetone, 2 -isobutylthiazole, and $\beta$-ionone) determined by enrichment of bland tomato homogenate with authentic volatile compound standards.

Statistical analyses. All GC and EN sensor output data were analyzed using multiple analysis of variance (MANOVA), Duncan's multiple range test for means separation, and forward stepwise multivariate discriminant analysis (MVDA) using STATISTICA 4.5 software package (Statsoft, Inc., 1994). The differences between volatile profiles found in ripe tomato samples were identified and visualized through MVDA, which created two-dimensional canonical plots where descriptive linear functions (canonical functions) classified the different tomato samples based on the pattern of outputs from the polymer sensors. In addition to MVDA, a forward stepwise procedure was utilized to optimize the number of variables considered for the descriptive linear functions, thus simplifying data collection and improving statistical significance.

\section{Results}

Whole TOMATo ANALYSES. The EN sensor array successfully segregated red-ripe tomatoes according to the ethylene exposure times required to reach breaker ( $100 \%$ posterior probability classification) (data not shown). In general, the individual polymer sensors showed significant increases in sensor response resulting from the interaction with volatile compounds present in the head- 


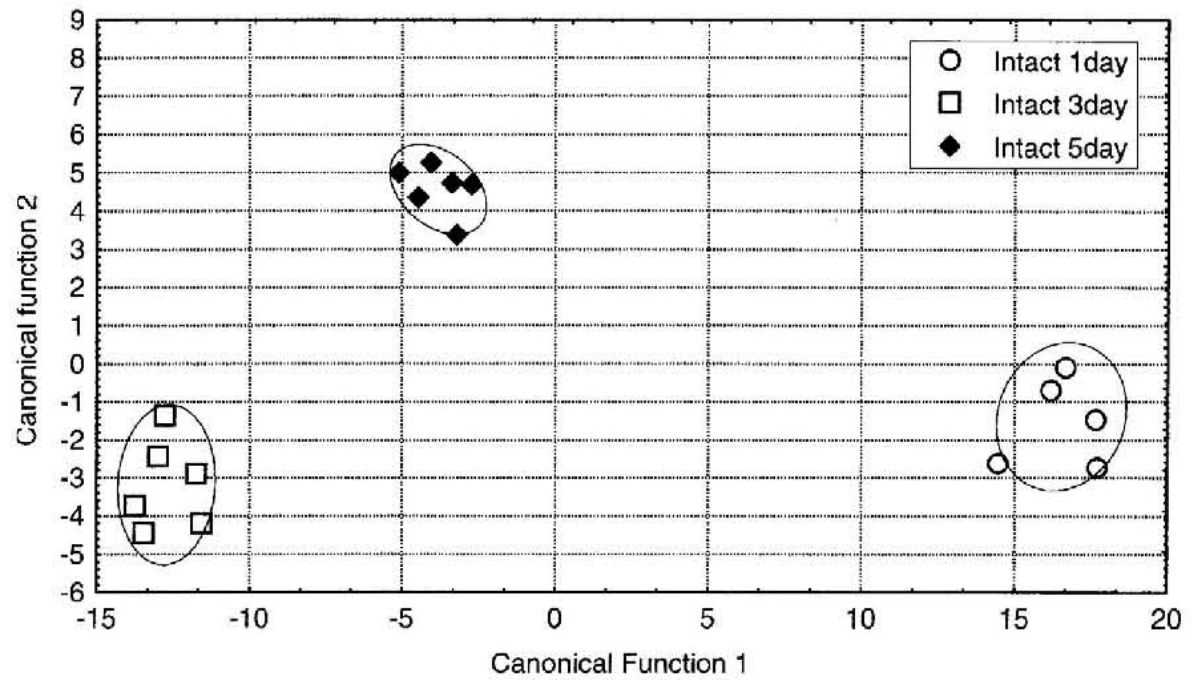

Fig. 1. Canonical plot from the multivariate discriminant analysis (MVDA) on electronic nose (EN) sensor outputs obtained when analyzing headspace volatiles present in intact ripe 'Solimar' tomatoes that had been exposed to $100 \mu \mathrm{L} \cdot \mathrm{L}^{-1}$ ethylene for 1,3 , or $5 \mathrm{~d}$ after harvest. The canonical plot represents the scores for canonical functions 1 and 2. Coefficients for canonical variables ( $E N$ sensors) are as follows: canonical function 1 ( $x$ axis $)=28.05$ sensor $t 301-38.86 t 298-$ $35.21 \mathrm{t} 297+37.04 \mathrm{t} 283+18.39 \mathrm{t} 278+52.87 \mathrm{t} 264-51.68 \mathrm{t} 263-24.17 \mathrm{t} 262-$ $4.14 \mathrm{t} 261+25.71 \mathrm{t} 260-42.58 \mathrm{t} 259+33.15 \mathrm{t} 258$. Canonical function $2(y$ axis $)=$ 9.41 sensor $\mathrm{t} 301-5.92 \mathrm{t} 298+0.12 \mathrm{t} 297+0.26 \mathrm{t} 283+4.09 \mathrm{t} 278+11.23 \mathrm{t} 264-$ $12.58 \mathrm{t} 263-8.33 \mathrm{t} 262+7.65 \mathrm{t} 261-4.62 \mathrm{t} 260-0.433 \mathrm{t} 259-1.11 \mathrm{t} 258$. The ellipses around ethylene treatment groupings represent $95 \%$ confidence areas. Distances between groupings were highly significant $(P<0.00018)$.

space of the sampling vessel. When compared to fruit, which required $1 \mathrm{~d}$ ethylene gas, eight out of the twelve polymer sensors showed significantly higher response $(P<0.05)$ when exposed to ripe fruit that required a 3 - or 5-d ethylene treatment. $\mathrm{RH}$ measurements inside the sampling vessel were signiticantly lower for intact fruit ( $26.90 \%$ to $29.90 \% \mathrm{RH}$ ) when compared to the homogenized tissue samples ( $62.0 \%$ to $71.4 \% \mathrm{RH}$ ) (data not shown).

To visualize the differences between the ethylene exposure treatments, a forward stepwise multivariate discriminant statistical analysis was employed. Three distinct clusters of points in the canonical plot illustrate resemblance among fruit from the same ethylene exposure treatments and dissimilarity between fruit from different ethylene exposure treatments (Fig. 1). The Mahalanobis distance (MD), the distance between the centroids of two clusters adjusted for probability (Srivastava and Carter, 1983), helped indicate the extent of differences between the ripe tomatoes. The greater the MD between clusters, the greater the dissimilarity between the treatments. According to the MD, the volatile profile differences between intact tomatoes which required 1 and $3 \mathrm{~d}$ gassing were greater than the differences between those that required 3 and $5 \mathrm{~d}$ gassing (32.09 and 12.90 units, respectively) (Table 1).

The GC aroma volatile profiles from homogenized tomatoes supported the differences identified by the EN output analysis. Generally, volatile levels were reduced in ripened fruit that required longer exposure to ethylene gas to reach breaker stage. Five of the sixteen aroma volatile compounds quantified showed significant differences as days gassing to breaker stage increased (Table 2). Ripe tomatoes which required 3 or $5 \mathrm{~d}$ of ethylene gassing showed significantly lower levels of 1 penten-3-one, cis-3-hexenal, 6-methyl-5hepten-2-one, 2-isobutythiazole and geranylacetone. In addition, ripe tomatoes that required $5 \mathrm{~d}$ ethylene gassing showed significantly lower levels of cis-3-hexenal and geranylacetone compared to fruit that required

\section{$3 \mathrm{~d}$ of ethylene treatment}

Results from the ANOVA showed that in the homogenate from tomatoes, which required a 3- or 5-d ethylene treatment, no sensor had increased response (electrical conductivity) when compared to the 1-d ethylene treatment (Table 3). However, the forward stepwise MVDA identified significant differences between the headspace volatiles present in homogenate samples and separated the three ethylene exposure time treatments (Fig. 2). The MD was significantly greater between homogenate samples, which required 1-d gassing and 3-d gassing when compared to the MD between the 3- and 5 -d gassing samples (24.14 and 6.52 units, respectively) (Table 1).

EXCISED TISSUE ANALYSES. To identify the fruit tissues responsible for the differences in volatile profiles, EN and GC analyses were conducted on excised tomato tissues. The ANOVA for pericarp (including columnella) homogenate showed significant increases in the sensor response compared to locular gel in six of twelve polymer sensors (Table 3). Forward stepwise MVDA from the sensor outputs successfully classified pericarp homogenate samples into three distinct clusters based on the length of ethylene treatment required to attain breaker stage (Fig. 3). The MD between 1- and 3-d gassing clusters was $175 \%$ greater than the distance between 3- and 5-d gassing clusters (116.31 and 65.04 units, respectively).

The volatile analyses from the same pericarp homogenate by GC showed a similar trend to that observed for whole fruit homogenate. Samples requiring $5 \mathrm{~d}$ of ethylene treatment had significant reductions in six important aroma volatile compounds (1-penten-3-one, trans-2-heptenal, 6-methyl-5-hepten-2-one, 2isobutylthiazole, geranylacetone and $\beta$-ionone) when compared to the 1- and 3-d ethylene treatments (Table 4). The pericarp tissue from fruit requiring the least ethylene treatment $(1 \mathrm{~d})$ showed

Table 1. Mahalanobis distances between clusters resulting from the multivariate discriminant analysis (MVDA) of electronic nose sensor outputs after exposure to ripe 'Solimar' tomato samples $(1-, 3-$, or 5-d ethylene treatment).

Tomato

Mahalanobis distances

between clusters ${ }^{2}$

sample

1 to $3 \mathrm{~d}$

1 to $5 \mathrm{~d}$

3 to $5 \mathrm{~d}$

Intact tomatoes

$32.09^{\mathrm{y}}$

23.23

Whole tomato homogenate

24.14

28.45

6.52

Pericarp (including columnella) homogenate

116.31

53.40

65.04

Locular gel homogenate

15.74

7.96

13.28

${ }^{\mathrm{z}}$ Mahalanobis distances were significant at the $1 \%$ level.

yepresents units of distance, adjusted for statistical probability, between the centroids of two distinct clusters of tomato samples. 
Table 2. Aroma volatile compound changes in ripe 'Solimar' whole tomato homogenate samples using gas chromatographic headspace analysis technique.

\begin{tabular}{|c|c|c|c|c|c|c|c|}
\hline \multirow{3}{*}{$\begin{array}{l}\text { Aroma } \\
\text { compound }\end{array}$} & \multirow{3}{*}{$\begin{array}{c}\text { Odor } \\
\text { threshold }^{2}\end{array}$} & \multicolumn{6}{|c|}{ Ethylene treatment } \\
\hline & & \multicolumn{2}{|c|}{$1 \mathrm{~d}$} & \multicolumn{2}{|c|}{$3 \mathrm{~d}$} & \multicolumn{2}{|c|}{$5 \mathrm{~d}$} \\
\hline & & Concn $^{y}$ & $\mathrm{OUV}^{x}$ & Conen & OUV & Concn & OUV \\
\hline Acetaldehyde & 2.50 & $12.64 \mathrm{a}$ & 5 & $13.54 \mathrm{a}$ & 5 & $12.04 \mathrm{a}$ & 5 \\
\hline Acetone & $\mathrm{NA}^{\mathrm{v}}$ & $0.45 \mathrm{a}$ & & $0.48 a$ & & $0.41 \mathrm{a}$ & \\
\hline Methanol & NA & $310.82 \mathrm{a}$ & & $304.13 \mathrm{a}$ & & $307.41 \mathrm{a}$ & \\
\hline Ethanol & 100.00 & $16.80 \mathrm{a}$ & 0.17 & $15.98 \mathrm{a}$ & 0.16 & $16.67 \mathrm{a}$ & 0.17 \\
\hline 1-Penten-3-one & $1 \times 10^{-3}$ & $0.27 \mathrm{a}$ & 271 & $0.19 \mathrm{~b}$ & 188 & $0.17 \mathrm{~b}$ & 169 \\
\hline Hexanal & $5 \times 10^{3}$ & $12.33 \mathrm{a}$ & 2,741 & $8.22 \mathrm{a}$ & 1,826 & $9.19 \mathrm{a}$ & 2,041 \\
\hline cis-3-Hexenal & $3 \times 10^{-4}$ & $9.04 \mathrm{a}$ & 36,168 & $6.18 b$ & 24,704 & $4.56 \mathrm{c}$ & 18,240 \\
\hline $2+3$ Methylbutanol & 0.3 & $2.16 \mathrm{a}$ & 9 & $2.26 \mathrm{a}$ & 9 & $1.79 \mathrm{a}$ & 7 \\
\hline trans-2-Hexenal & 0.02 & $8.59 \mathrm{a}$ & 505 & $7.51 \mathrm{a}$ & 442 & $7.03 \mathrm{a}$ & 414 \\
\hline trans-2-Heptenal & 0.02 & $0.04 \mathrm{a}$ & 3 & $0.03 \mathrm{a}$ & 2 & $0.03 \mathrm{a}$ & 2 \\
\hline 6-Methyl-5-hepten-2-one & 0.05 & $0.83 \mathrm{a}$ & 17 & $0.55 \mathrm{~b}$ & 11 & $0.42 \mathrm{~b}$ & 8 \\
\hline cis-3-Hexenol & 0.07 & $0.05 \mathrm{a}$ & 0.7 & $0.05 \mathrm{a}$ & 0.6 & $0.05 \mathrm{a}$ & 0.7 \\
\hline 2-Isobutylthiazole & $4 \times 10^{-3}$ & $0.09 \mathrm{a}$ & 25 & $0.06 \mathrm{~b}$ & 17 & $0.05 \mathrm{~b}$ & 15 \\
\hline 1-Nitro-phenylethane & $2 \times 10^{-3}$ & $0.06 \mathrm{a}$ & 31 & $0.06 \mathrm{a}$ & 29 & 0.05 & 27 \\
\hline Geranylacetone & 0.06 & $6.90 \mathrm{a}$ & 115 & $4.26 \mathrm{~b}$ & 71 & $2.25 \mathrm{c}$ & 37 \\
\hline$\beta$-Ionone & $7 \times 10^{-6}$ & $0.12 \mathrm{a}$ & 17,143 & $0.09 \mathrm{a}$ & 13,000 & $0.06 \mathrm{a}$ & 8,571 \\
\hline Total volatile compound concn ${ }^{u}$ & $\cdot$ & \multicolumn{2}{|c|}{381.18} & \multicolumn{2}{|c|}{363.58} & \multicolumn{2}{|c|}{362.65} \\
\hline
\end{tabular}

${ }^{7}$ Odor thresholds in water solutions $\left(\mu \mathrm{L} \cdot \mathrm{L}^{-1}\right)$ according to Buttery et al., 1988.

yeans for volatile concentrations $\left(\mu \mathrm{L} \cdot \mathrm{L}^{-1}\right)$ with different letters across rows are significantly different at the $5 \%$ level.

${ }^{\mathrm{x}} \mathrm{OUV}=$ odor unit values (concentration/odor threshold).

vNA = odor threshold not available for tomatoes.

"Total volatile concentration $\left(\mu \mathrm{L} \cdot \mathrm{L}^{-1}\right)$ based on the 16 compounds quantified.

significantly higher levels of cis-3-hexenal compared to the fruit from the 3- and 5-d ethylene treatments. Meanwhile, 2+3methylbutanol was highest in fruit from the 3-d ethylene treatment.

The ANOVA for locular gel homogenate showed no significant differences in sensor response between sensor outputs from the different ethylene treatments (Table 3). Meanwhile, the forward stepwise MVDA analysis segregated locular gel samples into three distinct clusters based on the pattern of differences between treatments (Fig. 4). The MD between the 1- and 3-d gassing clusters was similar to the distance between the 3 - and 5-d gassing clusters (15.74 and 13.28 units, respectively) (Table 1).

The GC aroma volatile profiles from the locular gel homoge- nate showed significant differences in five important compounds (Table 5). Locular gel samples from fruit that required 1-d ethylene gassing showed significantly higher levels of 1-penten-3-one, 2isobutylthiazole, 1-nitro-2-phenylethane, and $\beta$-ionone. Conversely, cis-3-hexenol levels increased significantly in samples that required $5 \mathrm{~d}$ of ethylene treatment.

\section{Discussion}

The Mahalanobis distances (MD) between clusters in all canonical plots (Figs. 1-4) show that ripe tomato samples produced significantly different volatile profiles as a function of the ethylene

Table 3. Electronic nose (EN) sensor response after exposure to ripe 'Solimar' tomato homogenate samples.

\begin{tabular}{|c|c|c|c|c|c|c|c|c|c|}
\hline \multirow{3}{*}{$\begin{array}{l}\text { EN } \\
\text { sensor }^{y}\end{array}$} & \multicolumn{9}{|c|}{ Sensor response $(\%)^{2}$} \\
\hline & \multicolumn{3}{|c|}{ Whole tomato } & \multicolumn{3}{|c|}{ Pericarp tissue } & \multicolumn{3}{|c|}{ Locular gel } \\
\hline & $1 \mathrm{~d}$ & $3 d$ & $5 \mathrm{~d}$ & $1 \mathrm{~d}$ & $3 d$ & $5 \mathrm{~d}$ & $1 \mathrm{~d}$ & $3 d$ & $5 d$ \\
\hline Type-301 & $3.27 \mathrm{a}$ & $3.39 \mathrm{a}$ & $3.39 \mathrm{a}$ & $3.24 \mathrm{a}$ & $3.21 \mathrm{a}$ & $3.14 \mathrm{a}$ & $3.23 \mathrm{a}$ & $3.21 \mathrm{a}$ & $3.26 \mathrm{a}$ \\
\hline Type-298 & $4.39 \mathrm{a}$ & $4.43 \mathrm{a}$ & $4.33 \mathrm{a}$ & $4.34 \mathrm{a}$ & $4.25 \mathrm{a}$ & $4.03 \mathrm{a}$ & $4.37 \mathrm{a}$ & $4.29 \mathrm{a}$ & $4.19 \mathrm{a}$ \\
\hline Type-297 & $4.31 \mathrm{a}$ & $4.32 \mathrm{a}$ & $4.26 \mathrm{a}$ & $4.26 \mathrm{a}$ & $4.16 \mathrm{a}$ & $3.97 \mathrm{~b}$ & $4.28 \mathrm{a}$ & $4.21 \mathrm{a}$ & $4.11 \mathrm{a}$ \\
\hline Type- 283 & $4.19 \mathrm{a}$ & $4.23 \mathrm{a}$ & $4.20 \mathrm{a}$ & $4.11 \mathrm{a}$ & $4.08 \mathrm{a}$ & $3.87 \mathrm{~b}$ & $4.14 \mathrm{a}$ & $4.10 \mathrm{a}$ & $4.00 \mathrm{a}$ \\
\hline Type-278 & $1.64 \mathrm{a}$ & $1.74 \mathrm{a}$ & $1.73 \mathrm{a}$ & $1.60 \mathrm{a}$ & $1.68 \mathrm{~b}$ & $1.61 \mathrm{a}$ & $1.60 \mathrm{a}$ & $1.67 \mathrm{a}$ & $1.64 \mathrm{a}$ \\
\hline Type-264 & $7.29 \mathrm{a}$ & $7.34 \mathrm{a}$ & $7.29 \mathrm{a}$ & $7.10 \mathrm{a}$ & $7.08 \mathrm{a}$ & $6.70 \mathrm{~b}$ & $7.27 \mathrm{a}$ & $7.13 \mathrm{a}$ & $6.94 \mathrm{a}$ \\
\hline Туре-263 & $5.67 \mathrm{a}$ & $5.78 \mathrm{a}$ & $5.71 \mathrm{a}$ & $5.51 \mathrm{a}$ & $5.54 \mathrm{~b}$ & $5.21 \mathrm{c}$ & $5.68 \mathrm{a}$ & $5.58 \mathrm{a}$ & $5.44 \mathrm{a}$ \\
\hline Type-262 & $2.50 \mathrm{a}$ & $2.62 \mathrm{a}$ & $2.60 \mathrm{a}$ & $2.41 \mathrm{a}$ & $2.45 \mathrm{a}$ & $2.35 \mathrm{a}$ & $2.49 \mathrm{a}$ & $2.49 \mathrm{a}$ & $2.44 \mathrm{a}$ \\
\hline Type-261 & $4.00 \mathrm{a}$ & $4.10 \mathrm{a}$ & $4.07 \mathrm{a}$ & $3.90 \mathrm{a}$ & $3.93 \mathrm{a}$ & $3.79 \mathrm{a}$ & $3.95 \mathrm{a}$ & $3.92 \mathrm{a}$ & $3.91 \mathrm{a}$ \\
\hline Type-260 & $3.92 \mathrm{a}$ & $4.00 \mathrm{a}$ & $3.93 \mathrm{a}$ & $3.84 \mathrm{a}$ & $3.82 \mathrm{ab}$ & $3.67 \mathrm{~b}$ & $3.86 \mathrm{a}$ & $3.82 \mathrm{a}$ & $3.79 a$ \\
\hline Type- 259 & $6.80 \mathrm{a}$ & $7.01 \mathrm{a}$ & $6.90 \mathrm{a}$ & $6.68 \mathrm{a}$ & $6.66 \mathrm{a}$ & $6.40 a$ & $6.75 \mathrm{a}$ & $6.68 \mathrm{a}$ & $6.70 \mathrm{a}$ \\
\hline Type-258 & $4.16 \mathrm{a}$ & $4.20 \mathrm{a}$ & $4.09 \mathrm{a}$ & $4.11 \mathrm{a}$ & $4.01 \mathrm{a}$ & $3.85 \mathrm{a}$ & $4.13 \mathrm{a}$ & $3.98 \mathrm{a}$ & $3.98 \mathrm{a}$ \\
\hline
\end{tabular}

${ }^{2}$ Responses from each EN polymer sensor after exposure to tomato samples were measured as \% increases over basal response levels. Sensor response values followed by different letters within each tomato tissue were significantly different at the $5 \%$ level.

${ }^{y}$ Individual polymer sensors were identified by a thrce-digit numeral code assigned by the manufacturer. 


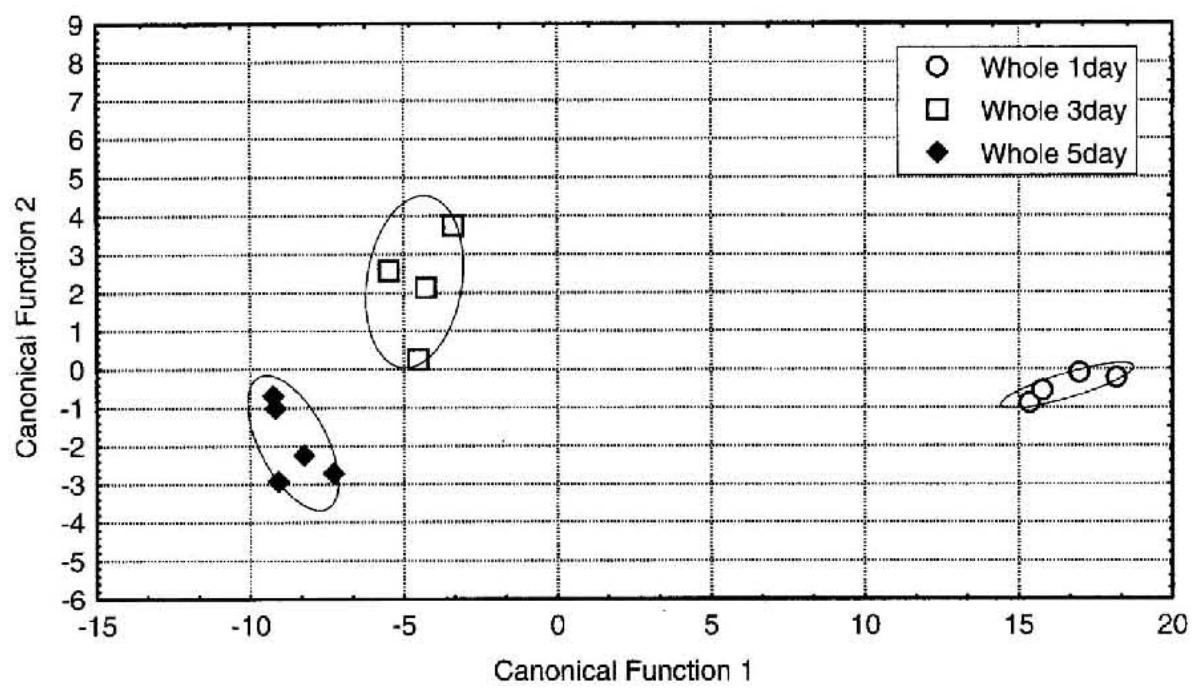

Fig. 2. Canonical plot from the multivariatc discriminant analysis (MVDA) on electronic nose (EN) sensor outputs obtained when analyzing headspace volatiles present in whole fruit homogenate from ripe 'Solimar' tomatoes that had been exposed to $100 \mu \mathrm{L} \cdot \mathrm{L}^{-1}$ ethylene for 1,3 , or $5 \mathrm{~d}$ after harvest. The canonical plot represents the scores for canonical functions 1 and 2. Coefficients for canonical variables (EN sensors) are as follows: canonical function 1 ( $x$ axis $)=-10.67$ sensor $\mathrm{t} 278-4.45 \mathrm{t} 283-26.54 \mathrm{t} 298-6.06 \mathrm{t} 30 \mathrm{l}-2.14 \mathrm{t} 263-22.47 \mathrm{t} 259+41.44 \mathrm{t} 260+$ $35.24 \mathrm{t} 297-6.27 \mathrm{t} 258$. Canonical function 2 ( $y$ axis $)=3.83$ sensor $1278-12.60 \mathrm{t} 283$ $+2.73 \mathrm{t} 298-2.42 \mathrm{t} 301+3.42 \mathrm{t} 263-5.68 \mathrm{t} 259+6.39 \mathrm{t} 260+4.83 \mathrm{t} 297-0.48 \mathrm{t} 258$. The ellipses around ethylene treatment groupings represent $95 \%$ confidence areas. Distances between groupings were very significant $(P<0.0066)$.

exposure time. The comparison in MD between clusters and the similarity in discriminant linear functions (canonical functions) from the MVDA suggest that there is a close relationship between intact tomato and tomato homogenate volatile profiles. Significantly lower relative humidity values recorded inside sampling vessel during EN analysis of intact fruit (when compared to homogenized tissues) could have contributed differences in sensor outputs between intact and homogenized tissues. The differences in whole tomato homogenate seem to be influenced considerably by significant changes in pericarp (including columnella) tissue volatile profiles. The MD observed between 1- and 3-d ethylene treatments in pericarp homogenate samples was $\approx 4.8$ and 7.4 times greater than that observed in whole tomato and locular gel homogenate, respectively (Table 1).

The GC headspace technique for identification and quantification of some important aroma volatile compounds present in tomato homogenate were useful to contrast the differences in volatile profiles observed from the EN analysis. There have been reports on the increased production of cis-3-hexenal, 6-methyl-5-hepten-2-one, geranylacetone, and $\beta$-ionone promoted by increased enzymatic activity resulting from tissue maceration (Buttery and Ling, 1993). However, when comparing EN sensor outputs from intact and homogenized whole tomatoes (Figs. 1 and 2), the separation between ethylene treatment groupings was similar. This could suggest that the significant differences in volatile profiles resulting from the different ethylene treatments (maturity at harvest) experience greater quantitative than qualitative changes as a result of tissue maceration. In the case of whole fruit, there is also the possibility of the volatile ethylene contributing to $\mathrm{EN}$ sensor conductivity changes. Tomatoes start producing their own ethylene during the mature green stages of ripening (M3-M4) (Brecht, 1987).

In general, individual aroma volatile compounds showing significant differences tended to decrease in concentration in immature fruit (requiring $>3$ - $\mathrm{d}$ ethylene treatment to initiate ripening). The differences in Mahalanobis distance between clusters observed in the MVDA could be partially explained by the total concentration of the 16 important aroma volatile compounds quantified during GC analysis. Pericarp homogenate samples produced $\approx 20 \%$ higher concentration of the volatile aroma compounds quantified, than whole tomato homogenate (443 and $369 \mu \mathrm{L} \cdot \mathrm{L}^{-1}$, respectively). Buttery et al. (1988) found similar results and suggested that this higher volatile production in pericarp tissue might be due to tissue damage during separation. Tissue wounding induces lipoxygenase activity, an important enzyme in the biosynthetic pathway of aldehydes and alcohols from membrane fatty acids (Hilderbrand, 1989). On the other hand, locular gel homogenate produced $43 \%$ lower total concentration of the 16 aroma volatile compounds $\left(203 \mu \mathrm{L} \cdot \mathrm{L}^{-1}\right)$. In tomatoes, the locular gel constitutes between $14.4 \%$ to $34 \%$ of the fresh mass (Stevens et al., 1977), thus showing the lesser contribution of the locular gel in the total production of volatile compounds by the whole fruit.

In addition to the total concentration of aroma volatile compounds, the number of individual compounds showing significant changes could help explain the differences found during the EN

Fig. 3. Canonical plot from the multivariate discriminant analysis (MVDA) on electronic nose (EN) sensor outputs obtained when analyzing headspace volatiles present in pericarp homogenate from ripe 'Solimar' tomatoes that had been exposed to $100 \mu \mathrm{L} \cdot \mathrm{L}^{-1}$ ethylene for 1,3 , or $5 \mathrm{~d}$ after harvest. The canonical plot represents the scores for canonical functions 1 and 2 . Coefficients for canonical variables (EN sensors) are as follows: canonical function 1 ( $x$ axis $)=72.15$ sensor $t 283+$ $20.36 \mathrm{t} 278-61.59 \mathrm{t} 262-138.30 \mathrm{t} 297+90.91+259-45.96 \mathrm{t} 2.58+28.89 \mathrm{t} 261+$ $55.84 \mathrm{t} 298-30.451260$. Canonical function $2(y$ axis $)=-17.22$ sensor $t 283+$ $2.81 \mathrm{t} 278+6.52 \mathrm{t} 262+16.34 \mathrm{t} 297-8.41+259+6.87 \mathrm{t} 258+1.05 \mathrm{t} 261-2.19 \mathrm{t} 298-$ $4.32 \mathrm{t} 260$. The ellipses aroundethylene treatment groupings represent $95 \%$ confidence areas. Distances between groupings were highly significant $(P<0.00001)$. The scale used for the canonical function 1 was increased compared to other fruit tissues to accommodate greater distances between pericarp tissue groupings.

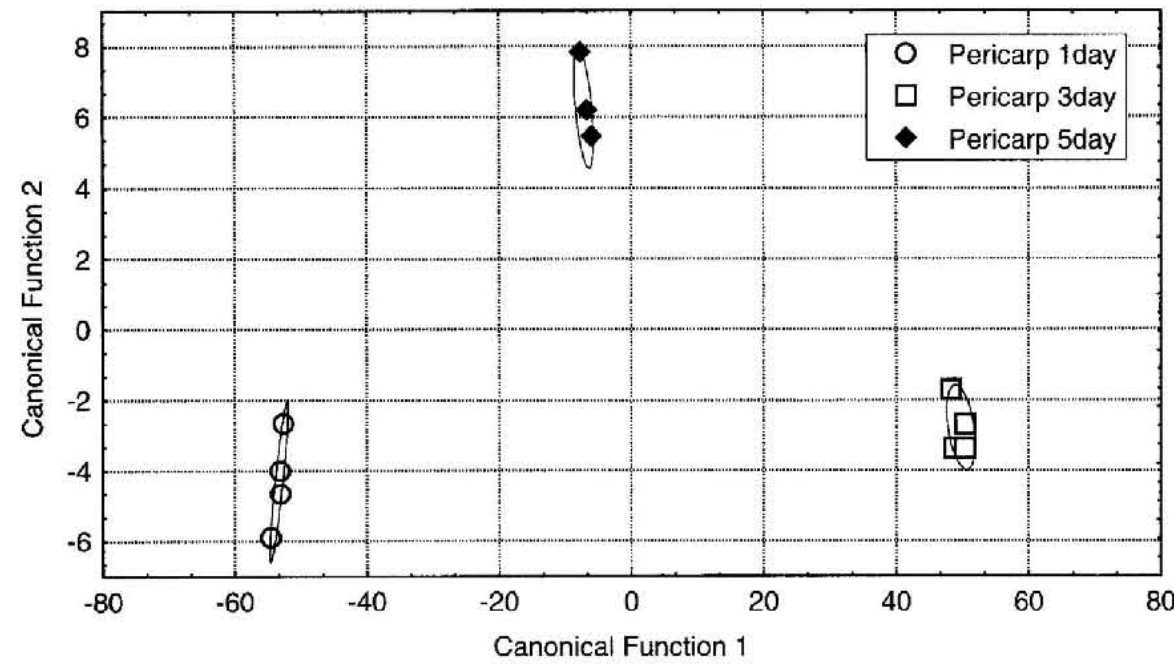


Table 4. Aroma volatile compound changes in ripe 'Solimar' tomato pericarp homogenate (including columnella) using gas chromatography-mass spectroscopy headspace analysis technique.

\begin{tabular}{|c|c|c|c|c|c|c|c|}
\hline \multirow{3}{*}{$\begin{array}{l}\text { Aroma } \\
\text { compounds }\end{array}$} & \multirow{3}{*}{$\begin{array}{c}\text { Odor } \\
\text { threshold }\end{array}$} & \multicolumn{6}{|c|}{ Ethylene treatment } \\
\hline & & \multicolumn{2}{|c|}{$1 \mathrm{~d}$} & \multicolumn{2}{|c|}{$3 \mathrm{~d}$} & \multicolumn{2}{|c|}{$5 \mathrm{~d}$} \\
\hline & & Concn $^{y}$ & OUV $^{x}$ & Concn & $\overline{\text { OUV }}$ & Conen & OUV \\
\hline Acetaldehyde & 2.50 & $14.53 \mathrm{a}$ & 6 & $16.27 \mathrm{a}$ & 7 & $11.97 \mathrm{a}$ & 5 \\
\hline Acetone & $\mathrm{NA}^{v}$ & $0.45 \mathrm{a}$ & & $0.47 \mathrm{a}$ & & $0.38 \mathrm{a}$ & \\
\hline Methanol & NA & 340.43 a & & $379.90 \mathrm{a}$ & & $375.78 \mathrm{a}$ & \\
\hline Ethanol & 100.00 & $22.84 \mathrm{a}$ & 0.23 & $18.06 \mathrm{a}$ & 0.18 & $17.99 \mathrm{a}$ & 0.18 \\
\hline 1-Penten-3-one & $1 \times 10^{-3}$ & $0.21 \mathrm{a}$ & 205 & $0.18 \mathrm{a}$ & 178 & $0.14 \mathrm{~b}$ & 144 \\
\hline Hexanal & $5 \times 10^{-3}$ & $19.43 \mathrm{a}$ & 4,318 & $14.09 \mathrm{a}$ & 3,131 & $14.90 \mathrm{a}$ & 3,312 \\
\hline cis-3-Hexenal & $3 \times 10^{-4}$ & $10.96 \mathrm{a}$ & 43,856 & $7.57 \mathrm{~b}$ & 30,288 & $6.45 \mathrm{~b}$ & 25,800 \\
\hline 2+3 Methylbutanol & 0.3 & $2.60 \mathrm{a}$ & 10 & $3.31 \mathrm{~b}$ & 13 & $2.18 \mathrm{a}$ & 9 \\
\hline trans-2-Hexenal & 0.02 & $9.78 \mathrm{a}$ & 575 & $8.66 \mathrm{a}$ & 510 & $6.98 \mathrm{a}$ & 411 \\
\hline trans-2-Heptanal & 0.02 & $0.05 \mathrm{a}$ & 4 & $0.04 \mathbf{a}$ & 3 & $0.03 \mathrm{~b}$ & 2 \\
\hline cis-3-Hexenol & 0.05 & $0.10 \mathrm{a}$ & 1 & $0.09 \mathrm{a}$ & 1 & $0.07 \mathrm{a}$ & 1 \\
\hline 6-Methyl-5-hepten-2-one & 0.07 & $0.95 \mathrm{a}$ & 19 & $0.76 \mathrm{a}$ & 15 & $0.50 \mathrm{~b}$ & 10 \\
\hline 2-Isobutylthiazole & $4 \times 10^{-3}$ & $0.11 \mathrm{a}$ & 30 & $0.09 \mathrm{a}$ & 25 & $0.05 b$ & 15 \\
\hline 1-Nitro-phenylethane & $2 \times 10^{-3}$ & $0.06 \mathrm{a}$ & 31 & $0.06 \mathrm{a}$ & 31 & $0.06 \mathrm{a}$ & 28 \\
\hline Geranylacetone & 0.06 & $7.55 \mathrm{a}$ & 126 & $5.92 \mathrm{a}$ & 99 & $3.66 \mathrm{~b}$ & 61 \\
\hline$\beta$-Ionone & $7 \times 10^{6}$ & $0.13 \mathrm{a}$ & 18,571 & $0.11 \mathrm{a}$ & 16,000 & $0.05 \mathrm{~b}$ & 7,285 \\
\hline Total volatile compound conen ${ }^{u}$ & & \multicolumn{2}{|c|}{430.64} & \multicolumn{2}{|c|}{455.56} & \multicolumn{2}{|c|}{441.19} \\
\hline
\end{tabular}

Z्रdor thresholds in water solutions $\left(\mu \mathrm{L} \cdot \mathrm{L}^{-1}\right)$ according to Buttery et al., 1988.

${ }^{y}$ Means for volatile concentrations $\left(\mu \mathrm{L} \cdot \mathbf{L}^{-1}\right)$ with different letters across rows are significantly different at the $5 \%$ level.

${ }^{x} \mathrm{OUV}=$ odor unit values (concentration/odor threshold).

"NA = odor threshold not available for tomatoes.

uTotal volatile concentration $\left(\mu \mathrm{L} \cdot \mathrm{L}^{-1}\right)$ based on the 16 compounds quantified.

analysis. The prolonged ethylene exposures required by immature-harvested fruit resulted in significant reductions in several important aroma compounds. The pericarp homogenate showed significant reductions in 8 out of 16 aroma compounds quantified, thus suggesting pericarp's greater susceptibility to harvest maturity. Even though the locular gel aroma seemed to be less affected by the treatments (five compounds showed significant reductions), still less than one-third of the aroma compounds quantified were significantly lower.

The significant decreases in the concentrations of $\beta$-ionone, cis3-hexenal, and 1-penten-3-one found in ripe, whole tomato homogenate samples, deserve special attention because of the high odor unit values for these compounds. The odor unit values (OUVs) represent a relationship between the concentration of a potential odorant present in a sample and the concentration required for sensory detection of such odorant. A high OUV for a volatile compound would imply that small changes in its concentration would have greater impact during sensory evaluation than similar magnitude changes in a low OUV volatile compound. The levels of $\beta$-ionone, the compound with one of the highest OUV, dropped by as much as $70 \%$ in locular gel samples which required extended ethylene treatment $(5 \mathrm{~d})$. In addition, geranylacetone levels dropped at least 50\% from 1- to 5-d ethylene treatments in all pericarp and whole tomato samples analyzed.

In whole fruit and pericarp samples that required $3 \mathrm{~d}$ of ethylene gassing, levels of hexanal dropped $33.4 \%$ and $27.5 \%$, respectively, although, these differences were not significant when compared to the 1-d ethylene samples. It is important to note, however, that methanol and hexanal concentrations were approximately $100 \%$ and $300 \%$ higher in the pericarp homogenate than in the locular gel homogenate. Higher concentrations of hexanal present in the pericarp tissue could indicate its higher contribution to the percep-

Fig. 4. Canonical plot from the multivariate discriminant analysis (MVDA) on electronic nose (EN) sensor outputs obtained when analyzing headspace volatiles present in locular gel homogenate from 'Solimar' tomatoes that had been exposed to $100 \mu \mathrm{L} \cdot \mathrm{L}^{-1}$ ethylene for 1,3 , or $5 \mathrm{~d}$ after harvest. The canonical plot represents the scores for canonical functions 1 and 2 . Coefficients for canonical variables (EN sensors) are as follows: canonical function $1(x$ axis $)=9.19$ sensor $1264-$ $6.46 \mathrm{t} 278+5.10 \mathrm{t} 301+7.57 \mathrm{t} 263+29.83 \mathrm{t} 260-27.05 \mathrm{t} 283-20.47 \mathrm{t} 262+3.87 \mathrm{t} 259$ Canonical function $2(y \mathrm{axis})=4.36$ sensor $\mathrm{t} 264-3.35 \mathrm{t} 278-0.54 \mathrm{t} 301-8.24 \mathrm{t} 263$ $-4.88 \mathrm{t} 260+6.16 \mathrm{t} 283+6.96 \mathrm{t} 262-0.96 \mathrm{t} 259$. The ellipses around ethylene trcatment groupings represent $95 \%$ confidence areas. Distances between groupings were highly significant $(P<0.0012)$.

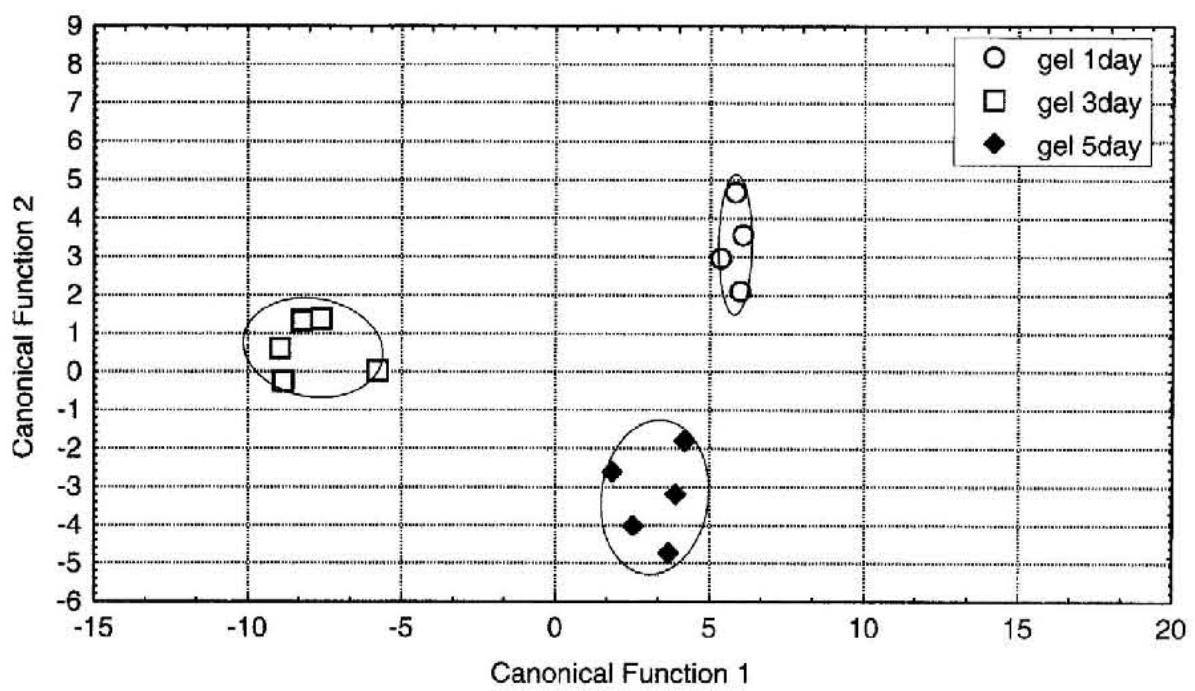


tion of green/grassy aroma/flavor descriptors reported by other descriptive sensory panels (Petro-Turza, 1987). cis-3-Hexenol levels decreased significantly in pericarp homogenate with increasing length of ethylene treatment. An increasing trend for the same compound was observed in locular gel homogenate (Table 5). The possibility of opposite trends in the production of volatile compounds from different tomato tissues might help explain the lesser degree of difference found in whole tomato homogenate when compared to pericarp homogenate. Three important aroma volatile compounds showed significant reductions in all tomato samples analyzed 1-penten-3-one, $\beta$-ionone, and 2 -isobutylthiazole, the latter deserving special attention since it is a compound unique to tomato aroma (Petro-Turza, 1987).

Reported aroma volatile concentrations from different tomato tissues (Buttery et al., 1988) do not entirely concur with our present results. Contrary to previous reports on the contribution of excised tissues to whole fruit volatile profiles, in 1-d ethylene treatment samples, the concentrations of 6-methyl-5-hepten-2-one and geranylacetone were lower in locular gel homogenate when compared to pericarp homogenate. With extended ethylene exposure time, locular gel homogenate produced slightly higher levels of the two compounds than the pericarp homogenate. The extent of these discrepancies might be related to cultivar variability as was shown by Baldwin et al. (1991b) and by maturity at harvest as indicated in this study. Nevertheless, the absolute levels of $\beta$-ionone, geranylacetone, 2+3-methylbutanol and 6-methyl-5-hepten-2-one were considerably higher in our results compared to those reported by Buttery et al. (1988).

Preliminary difference/discrimination sensory tests have confirmed the perception of significant differences between samples of tomato homogenate, which required $1 \mathrm{~d}$ of ethylene and those that required 3 and $5 \mathrm{~d}$ of ethylene before reaching breaker stage (Sargent et al., 1997). The significant differences in the GC aroma volatile profiles from ripe fruit from different ethylene gassing treatments support the conclusion that ripe tomato flavor may indeed be affected by maturity at harvest (M1 to M4). We suggest that the reported reductions in six important aroma volatiles (hexanal, 6-methyl-5heptene-2-one, geranylacetone, 1-penten-3-one, methanol, 2+3methylbutanol, and 1-nitro-2-phenylethane) by McDonald et al. (1996) were not entirely a direct effect of ethylene treatment but rather a consequence of fruit maturity at harvest.

Green-harvested 'Solimar' tomatoes showed significant changes in aroma volatile profiles as a function of the exposure time to ethylene required to attain breaker stage (which is related to physiological maturity at harvest). The EN was able to discriminate between the different ripe tomato samples from the different ethylene treatments (i.e., harvest maturities) and these results were contrasted to $\mathrm{GC}$ aroma volatile profile changes. The pericarp tissue showed higher concentrations of some of the important aroma compounds quantified, an observation that might downplay the importance of locular gel fluidity in the impact of flavor perception during mastication. However, as noted earlier, this could also be due to a wound response when separating the tissues.

Aroma volatile compounds have been proposed to have a significant effect on the human perception of tomato flavor (Kader et al., 1977; Petro-Turza, 1987). Even after extensive research on tomato flavor compounds there is little definitive information on the relationship between flavor/aroma compounds and sensory flavor perception. The use of new technologies such as the EN may prove useful in correlating instrumental measurements to results from sensory panel evaluations. In this study the EN sensor array proved to be successful in nondestructively classifying tomatoes based on the length of ethylene exposure required before external ripening symptoms were evident (relating to harvest maturity: M1-M4). This nondestructive screening approach may be useful for future commercial operations once analysis times become rapid enough to permit real-time analysis on industry and sorting lines.

Table 5. Aroma volatile compound changes in ripe 'Solimar' tomato locular gel homogenate using gas chromatography-mass spectroscopy headspace analysis technique.

\begin{tabular}{|c|c|c|c|c|c|c|c|}
\hline \multirow{3}{*}{$\begin{array}{l}\text { Aroma } \\
\text { compounds }\end{array}$} & \multirow{3}{*}{$\begin{array}{c}\text { Odor } \\
\text { threshold }\end{array}$} & \multicolumn{6}{|c|}{ Ethylene treatment } \\
\hline & & \multicolumn{2}{|c|}{$1 \mathrm{~d}$} & \multicolumn{2}{|c|}{$3 d$} & \multicolumn{2}{|c|}{$5 d$} \\
\hline & & Concn ${ }^{y}$ & OUV $^{x}$ & Conen & OUV & Concn & OUV \\
\hline Acetaldehyde & 2.50 & $19.95 \mathrm{a}$ & 8 & $17.43 \mathrm{a}$ & 7 & $16.45 \mathrm{a}$ & 7 \\
\hline Acetone & $\mathrm{NA}^{\mathrm{v}}$ & $0.49 \mathrm{a}$ & & $0.48 \mathrm{a}$ & & $0.47 \mathrm{a}$ & \\
\hline Methanol & NA & $146.63 \mathrm{a}$ & & $144.74 \mathrm{a}$ & & $136.33 a$ & \\
\hline Ethanol & 100.00 & $18.84 \mathrm{a}$ & 0.19 & $19.33 \mathrm{a}$ & 0.19 & $18.78 \mathrm{a}$ & 0.19 \\
\hline 1-Penten-3-one & $1 \times 10^{-3}$ & $0.18 \mathrm{a}$ & 179 & $0.12 \mathrm{~b}$ & 124 & $0.14 \mathrm{~b}$ & 138 \\
\hline Hexanal & $5 \times 10^{-3}$ & $4.10 \mathrm{a}$ & 911 & $3.02 \mathrm{a}$ & 671 & $4.78 \mathrm{a}$ & 1,062 \\
\hline cis-3-Hexenal & $3 \times 10^{-4}$ & $6.53 \mathrm{a}$ & 26,124 & $4.89 \mathrm{a}$ & 19,564 & $5.59 \mathrm{a}$ & 22,344 \\
\hline $2+3$ Methylbutanol & 0.3 & $2.38 \mathrm{a}$ & 10 & $2.66 \mathrm{a}$ & 11 & $2.95 \mathrm{a}$ & 12 \\
\hline trans-2-Hexenal & 0.02 & $6.83 \mathrm{a}$ & 402 & $5.99 \mathrm{a}$ & 353 & $7.55 \mathrm{a}$ & 444 \\
\hline trans-2-Heptenal & 0.02 & $0.03 \mathrm{a}$ & 2 & $0.03 \mathrm{a}$ & 2 & $0.03 a$ & 2 \\
\hline 6-Methyl-5-hepten-2-one & 0.05 & $0.64 \mathrm{a}$ & 13 & $0.52 \mathrm{a}$ & 10 & $0.56 \mathrm{a}$ & 11 \\
\hline cis-3-Hexenol & 0.07 & $0.07 \mathrm{a}$ & 1 & $0.09 \mathrm{ab}$ & 1 & $0.14 \mathrm{~b}$ & 2 \\
\hline 2-Isobutylthiazole & $4 \times 10^{-3}$ & $0.11 \mathrm{a}$ & 32 & $0.63 \mathrm{~b}$ & 18 & $0.07 \mathrm{~b}$ & 21 \\
\hline 1-Nitro-phenylethane & $2 \times 10^{-3}$ & $0.07 \mathrm{a}$ & 34 & $0.06 \mathrm{~b}$ & 30 & $0.06 \mathrm{~b}$ & 29 \\
\hline Geranylacetone & 0.06 & $2.98 \mathrm{a}$ & 50 & $2.69 \mathrm{a}$ & 45 & $2.72 \mathrm{a}$ & 45 \\
\hline$\beta$-Ionone & $7 \times 10^{-6}$ & $0.22 \mathrm{a}$ & 31,857 & $0.17 \mathrm{ab}$ & 24,000 & $0.08 \mathrm{~b}$ & 11,571 \\
\hline \multicolumn{2}{|c|}{ Total volatile compound concn } & \multicolumn{2}{|c|}{210.05} & \multicolumn{2}{|c|}{202.28} & \multicolumn{2}{|c|}{196.68} \\
\hline
\end{tabular}

${ }^{\mathrm{z}}$ Odor thresholds in water solutions $\left(\mu \mathrm{L} \cdot \mathrm{L}^{-1}\right)$ according to Buttery et al., 1988.

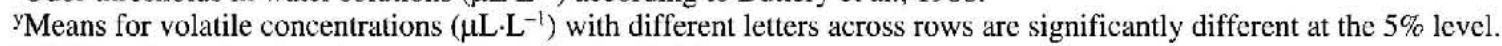

${ }^{x}$ OUV $=$ odor unit values (concentration/odor threshold).

${ }^{\mathrm{N} A}=$ odor threshold not available for tomatoes.

uTotal volatile concentration $\left(\mu \mathrm{L} \cdot \mathrm{L}^{-1}\right)$ based on the 16 compounds quantified. 


\section{Literature Cited}

Al-Shaibani, A.M.H. and J.K. Greig. 1979. Effects of maturity, storage, and cultivar on some quality attributes of tomatoes. J. Amer. Soc. Hort. Sci. 104(6):880-882.

Neotronics Scientific Inc. 1996. An introduction to electronic nose technology. Neotronics Scientific Inc., Flowery Branch, Ga. p. 12-56.

Baldwin, E.A., M.O. Nisperos-Carriedo, and J.W. Scott. 1991a. Levels of flavor volatiles in a normal cultivar, ripening inhibitor and their hybrid. Proc. Fla. State Hort. Soc. 104:86-89.

Baldwin, E.A., M.O. Nisperos-Carriedo, R. Baker, and J.W.Scott. 1991b. Quantitative analysis of flavor parameters in six Florida tomato cultivars. J. Agr. Food Chem. 39:1135-1140.

Brecht, J.K. 1987. Locular gel formation in developing tomato fruit and the initiation of ethylene production. HortScience 22(3):476-479.

Buttery R.G. and L.C. Ling. 1993. Volatile components of tomato fruit and plant parts: Relationship and biogenesis, p. 23-34. In: R. Teranishi, R. Buttery, and H. Sugisawa (eds.). Bioactive volatile compounds from plants. Amer. Chem. Soc., Washington, D.C.

Buttery, R.G., R. Teranishi, L. Ling, and J.G. Turnbaugh. 1990. Quantitative and sensory studies on tomato paste volatiles. J. Agr. Food Chem 38:336-340.

Buttery, R.G., R. Teranishi, L. Ling, R.A. Flath, and D. Stern. 1988. Quantitative studies on origins of fresh tomato aroma volatiles. J. Agr. Food Chem. 36:1247-1250.

Chomchalow, S. 1991. Storage conditions and timing of ethylene treatment affect uniformity and marketability of tomato fruit. Univ. Florida MS thesis.

Gull, D., D. Cartagena, and E.C. French. 1980. Analisis de calidad de tomate para lograr un mejor producto (in Spanish). IBTA, PRODES, UFLA, Cochabamba, Bolivia. p. 20.
Hardenburg, R.E., A.E. Watada, and C.Y. Wang. 1986. The commercial storage of fruits, vegetables, and florist and nursery stocks. USDA-ARS Agr. Hndbk. 66. p. 11-12.

Hilderbrand, D.F. 1989. Lipoxygenases. Physiol. Plant. 76:249-253.

Kader, A.A., M.A. Stevens, M. Albright-Holton, L.L. Morris, and M. Algazi. 1977. Effect of fruit ripeness when picked on flavor and composition in fresh market tomatoes. J. Amer. Soc. Hort. Sci. 102(6):724-731.

Kader, A.A. and L.L. Morris. 1976. Correlating subjective and objective measurements of maturation and ripeness of tomatoes. In: Proc. 2nd Tomato Quality Wkshp. Veg. Crops Ser. 178. Univ. of Calif., Davis.

Kavanagh, E.E., W.B. McGlasson, and R.L. McBride. 1986. Harvest maturity and acceptability of 'Flora-Dade' tomatoes. J. Amer. Soc. Hort. Sci. 111(1):78-82.

McDonald, R.E., T.G. McCollum, and E.A. Baldwin. 1996. Prestorage heat treatments influence free sterols and flavor volatiles of tomatoes stored at chilling temperature. J. Amer. Soc. Hort. Sci. 121(3):531-536.

Petro-Turza, M. 1987. Flavor of tomato and tomato products. Food Rev. Intl. 2(3):309-351.

Sargent, S.A., F. Maul, C.L. Moretti, and C.A. Sims. 1997. Harvest maturity, storage temperature and internal bruising affect tomato flavor. Proc. 1997 Fla. Tomato Inst., IFAS, Univ. Florida. p. 22-24.

Srivastava, M.S. and E.M. Carter. 1983. An introduction to applied multivariate statistics. Elsevier Science, New York.

Statsoft Inc. 1994. STATISTICA for Windows version 4.5. Statsoft Inc., Tulsa, Okla.

Stevens, M.A., A.A. Kader, and M. Albright-Holton. 1977. Intercultivar variation in composition of locular and pericarp portions of fresh market tomatoes. J. Amer. Soc. Hort. Sci. 102(5):689-692.

Watada, A.E. and B.B. Aulenbach. 1979. Chemical and sensory qualities of fresh market tomatoes. J. Food Sci. 44:1013-1016. 